\title{
Zgaga, P., Teichler, U., \& Brennan, J. (Eds.) (2012). The Globalisation Challenge for European Higher Education / Convergence and Diversity, Centres and Peripheries. Frankfurt/M.: Peter Lang. 389 pp., ISBN 978-3-631- 6398-5.
}

Reviewed by DARKo ŠTrAJN ${ }^{1}$

The present book suggests that the notion of "globalisation" is not only a content- empty term, but an unavoidable overarching concept. It covers a long chain of events, realities, ideas, views and standpoints, perhaps simply including many meanings of words that designate the complexities we have to deal with. Higher education is an extremely complex "organism" within the wider complexities of social spaces, cultural diversities, economic relationships and representations in a variety of relevant and irrelevant discourses. The editors and authors of this book, which is an insightful product of a range of institutionally and informally based academic interactions, were obviously aware that the developments in European higher education systems expose the aforementioned chain of meanings to different perceptions and to critical scrutiny. Hence, terms such as Europeanisation, internationalisation, diversification, etc., became linked to "Bolognisation" as an underlying, ongoing process present both before and after the introduction of the crucial declaration in Bologna at the end of the previous millennium. In their introduction to the book, the editors point out that: "The Zeitgeist called for the creation of more 'unity' in the European 'diversities'; it was in this context that the political momentum was accumulated to establish the European Higher Education Area (EHEA)" (p. 13). However, the intention to create more unity in diversity rearranged the pattern in which particular nations and regions stand against each other as parts of "centres" and "peripheries". As the editors hint, trends are also taking opposite directions to those prevalent at the start of the process. Of course, the editors do not try to simplify the complex outcomes of the "process" of the last two decades; they stress the importance of research and critical analysis, which are actually performed in fifteen chapters in the three parts of this interesting and engaging book. The contributors provide well-grounded observations and numerous research-based considerations of different aspects, contexts and spaces in which "Bologna" has instigated many changes in accordance and/or in conflict with social changes. However, the book as a whole suggests that the

1 Educational Research Institute (Pedagoški inštitut), Ljubljana, Slovenia 
way forward starts by taking into account the different phenomena, realities, frameworks and perspectives of European higher education. Although all of the contributions share a common spirit, they also make the particular chapters diverse and specific, which in the end makes us see the big picture of the EHEA after years of transformations.

Part 1 of the book examines the Front Issues. In the first text of this part, Janja Komljenovič and Klemen Miklavič concentrate on the discourses generated by EU institutions. Under the title Imagining Higher Education in the European Knowledge Economy, the authors point to the fact that nation-state boundaries have been crossed, creating "new arenas of policy making" (p. 339). The chapter then goes on to show how the documents of EU institutions above all reflect the economic imaginary, i.e., the economic instrumentalisation of higher education based on the paradigm of the so-called knowledge society. The history of interacting concepts and actions in the area of the EHEA points towards a supranational "new constitutionalism." The next paper by Ulrich Teichler, The Event of International Mobility in the Course of Study, deals with the cross-border mobility of students as "a key policy objective in Europe" (p. 55). Unfortunately, this is not evident in statistics, which Teichler very precisely reveals as being extremely untrustworthy by citing many aspects of imprecise meaning, definitions, etc. Still, the author gives some interesting estimations, stating that, in his critical judgment, international mobility, as one of the main objectives of the Bologna reform, appears to be only vaguely attained. I must add that this is one of the best recent papers I have came across that distinguishes between policy declarations and hard facts; indeed, the paper is as enjoyable to read as a crime story. Ellen Hazelkorn and Martin Ryan examine The Impact of University Rankings on Higher Education Policy in Europe. This chapter does not question the methodology and purpose of University rankings, but in its conclusion argues "that the emergence of global university rankings was not only a challenge to the perceived wisdom about the status and reputation of European higher education, but has stimulated significant changes in European higher education policy" (p. 94). There should be more research in this area, as this chapter remains focused primarily on three central countries: France, Germany and the UK. The reader learns the difference between Bildung (education) and Ausbildung (vocational education and training) through the chapter written by Elsa Hackl: Diversification in Austrian Higher Education. The author somewhat reluctantly acknowledges the impact of the EU on the national level, and especially on the process of the diversification of higher education. Researchers in other countries should take Hackl's contribution as a good example and do their own thinking about national and supranational influences 
in what, over last two decades, has been labelled as the modernisation of higher education. That which Manja Klemenčič had in mind when writing about "diversification" is slightly different from Hackl's definition. In her article The Effects of Europeanisation on Institutional Diversification in the Western Balkans, Klemenčič presents a case study on four Balkan countries: Slovenia, Serbia, Croatia and Albania. The paper undoubtedly demonstrates how tricky introducing European policies - in order to achieve the goals of accessibility and excellence at the same time - can become when it comes to legislation involving new mechanisms to stimulate diversification of aims and quality within a system. The author determines that Slovenia and Croatia have come closer to European goals than the other countries studied. Still, it seems that Klemenčič sees the benefit of the whole process in strengthening research excellence as "the single most powerful element of institutional diversification" (p. 135).

The next five papers in Part 2 of the book are grouped around the topics of Massified and Internationalised Higher Education. The first chapter, The Monolithic Un-intentionality of Higher Education Policies, written by Voldemar Tomusk, invokes "Karl Marx, Joseph Stalin and the minor classics less known". Tomusk critically challenges a number of established beliefs and notions concerning higher education, building on some broad arguments by such authors as Trow and Clark. In such a brief overview of the whole book, it is impossible to present the scope of this paper. It makes a witty, critical and even somewhat provocative point about the contradictions of the reform process, which unintentionally "fights vigorously" thinking and knowledge. I cannot resist the temptation to observe that this paper reminds one of the spirit of the 1960s and the push for the democratisation of higher education in those times. Close to this spirit is the next chapter by Susan L. Robertson "Hullabaloo in the Groves of Academe". The author deals with recent British changes - of course, also taking into account the history - aimed at developing a "competitive higher education market open to for-profit providers". After a rather detailed examination of leading notions and policies, Robertson arrives at a conclusion that should be taken as an axiom: "The differentiation of higher education institutions cannot be separated from the differentiation of the societies of which they are part" (p. 198). Leon Cremonini's assertion that "the preoccupation with league tables and excellence may lead to a state of bellum omnium contra omnes that is detrimental rather than beneficial to higher education systems and societies" (p. 201) should be taken very seriously if we are ever going to contemplate going back to the emphasis on social equality as a structuring principle of higher education. Otherwise, Cremonini, in his chapter The Recognition of Prior Learning and Dutch Higher Education, gives a detailed overview of what is going on in the 
Dutch system and in the policies surrounding it, arriving at the conclusion that recognition of acquired competences "has the potential to address inequality in higher education" (p. 226). The following chapter, From System Expansion to System Contraction by Marek Kwiek, provides rich information on developments in Poland, where - similarly to in other post-communist transition countries - a wave of expansion of higher education has been followed by contraction, above all due to demographic causes. Apart from this, Kwiek examines public-private relations in light of the consequences for access to higher education.

Part 3 of this overall inspiring book is focused on Higher Education in Eastern and South-East Europe. The chapter written by Martina Vukasović and Mari Elken, entitled Higher Education Policy Dynamics in a Multi-level Governance Context, is a good example of a comparative study, involving four countries (Croatia, Estonia, Slovenia and Serbia). The authors analyse meanings of the label 'Europeanisation' within a context that they uncover by presenting the results of their inquiries into some recent developments, which, due to the Bologna process, have to an extent shifted the focus of changes to international concerns. Jana Baćević provides a very informative, instructive and condensed overview of higher education in the post-Yugoslav space in her chapter What Kind of University for What Kind of Society? At the same time, Baćević takes care to critically repudiate any doctrinal approaches to the notion of society and its higher education. On the basis of her study of the changes in higher education in the Western Balkans, she clearly corroborates changed social realities, since "the 'society' that universities are supposed to 'belong' to has changed" (p. 305). The Bosnian Puzzle of Higher Education in the Perspective of the Bologna Process by Tatjana Sekulić is another chapter that examines a very specific country of the 'periphery'. The article provides quite ample information on the main historical traits of Bosnian higher education and describes the political and social framework of the implementation of "Bologna" from 2007 onwards, when the legal basis was introduced. Bosnia could be one of the rare countries where academics - if we are to believe what some of Sekulićs interviewees report - see more positive than negative impacts of the reform. Higher education reform otherwise came in a package of complex solutions for this war-torn country, now slowly making its way towards the EU. Drawing on some critical educational and social theorists such as Giroux, Apple, Saunders and others, in the chapter Reclaiming the Role of Higher Education in Croatia, Danijela Dolenec and Karin Doolan present a case study focusing on the recent Croatian student movement. With the extended critical and theoretical opening section of the paper, the authors clearly join the ranks of the rapidly growing numbers of thinkers in the field of education studies who are developing 
analyses of the neoliberal economy and politics and their disastrous impact on education, particularly in the domain of higher education. The student movement in Croatia is resisting the privatisation, commodification and marketisation of universities in favour of the accessibility of education and a redefinition of its social role. In the final chapter, Reconsidering Higher Education Reforms in the Western Balkans, Pavel Zgaga reflects on higher education reforms in the Western Balkans (comprising all former Yugoslav republics plus Albania). Zgaga focuses particular attention on notions of "centre and periphery", and in this light ponders shifts, developments, positions and perceptions concerning the aforementioned peripheral countries. He provides well-founded reasons to doubt the simple idea that these countries just happen to be areas of colonisation within the currents of globalisation and the implementation of "Bologna." At the same time, some tendencies in the direction of autarchy cannot be generalised as prevailing trends. However, an important feature of this chapter is its conceptually clear narrative, which presents the most important historical facts and relevant developments in the area of higher education before, during and after the Bologna reform.

As seen by the contributors to the present volume, the Bologna reform (as an agency of globalisation) is entering a period of critical evaluation, theoretical reflection and possibly thorough revision. Still, as most of the contributors point out, "Bologna" makes up part of the globalisation process in its best and worst features. In its form and content, this book is one of the pioneering steps forward in the context of recent efforts to reconsider the role of higher education. The relationship between centres and peripheries - by virtue of their existence and irrespective of the different views on them - seems to be the crucial element by which "success" or failure of the EHEA could be judged in the not so distant future - provided that there is a future beyond the neoliberal world and its power frameworks. 